\title{
New Media and Sectarianism in Indonesia
}

\author{
Dedy Djamaluddin Malik \\ Sekolah Tinggi Ilmu Komunikasi (STIKOM) \\ Bandung, Indonesia \\ dedy_malik@yahoo.com
}

\begin{abstract}
This article provides a descriptive lens of the emergent hate-speech that has been spreading in various new media as result of the religious sectarianism interests in Islamic community. The reinforcements of sectarianism in Indonesian Islamic community is not separated from global turbulences and political constellation in the Middle East. The result of religious sectarianism has produced a social distance, prejudice and social conflict in the Islamic community. By using theoretical framework of Jurgen Habermas's deliberative democracy, the writer seeks for a solution to transform hate-speech in new media into peaceful dialogical communication, full respect and deep mutual understanding of each Islamic community.
\end{abstract}

Keywords—new media; sectarianism; hate speech; deliberative democracy

\section{INTRODUCTION}

Today, the new communication technology has been affecting the Muslim environment and it has become a new reality [1]. By using the new media, or digital media [2], the way they communicate, both internal and external communities, become various. Then, it appears the terms eIslam, e-propaganda, e-dakwa, e-jihad, and so forth. Their activities on new media are depicted by [3] as a "Cyber Islamic Environments" (CIES). It's not surprising if, "all scholars of religious studies as well as media studies now have to consider seriously the interplay between religion and media [4]. The new field in media and religious studies have appeared. Campbell [5] describes the emerging of religious discourse on the new media, often referred to as "digital religion".

Generally speaking, the emerging of new media will expand the Islamic enlightenment to Muslim communities. It can enriches the Islamic horizon of the variety of traditions, doctrines, practices, and cultural landscape of Muslim communities. It will enhance a communication with more mutual understanding, dialogical, rational, and empathy of one another. In this context, new media will open, what Habermas's termed, deliberative democracy, means that democracy should be performed by strong argumentation [6].

However, in contrary, Muslim communication on the new media, has been facing deficit discourses. Islam Dot Com was contented by the existence of highly fragmenting variables between various Islamic groups" [7]. New media used by Islamic groups to proliferate their sectarian's school of thought $(m a z h a b)$ and political interests. Emotional discourse on the ground of Islamic sectarianism, can be termed 'cyber-sectarian conflict' [8]. Most of them used new media to marginalize and blaspheme each other, as heterodox.

Indonesian Muslim online nowadays are marked by using hate speech profoundly. By quoting Soreal [9] defines "hate speech" as a broad term used to describe speech which attacks others on the grounds of their race, nationality, religious identity, gender, sexual orientation or other group membership". Meanwhile Kathrine defines hate speech is regarded as "speech which is particularly harmful because it contributes to a climate of hatred and violence towards marginalized and disempowered sectors of community" [10].

The research questions proposed are: (1) How do Muslim sectarians expressing hate speech on new media/; (2) Why sectarianism symptom has become more strengthening in recent years; and (3) How can the hate speech among Muslim communities be eliminated in the future?

\section{RESARCH METHODS}

The research method used was secondary data by collecting data of Muslim websites affiliated with sectarian interest. Its data were taken from Indonesian Muslim sectarian websites belong to Wahabi-Salafi, Shia and Ahmadiya and being compared with Middle East Muslim sectarian websites. The method of analysis is critical discourse analysis. Unit analysis was focused on some of words that contain aggressive communication (hate speech) such as: labelling, insulting, flaming and bullying.

The paradigm used in this paper is critical approach assuming that the practices of communication happened in society, contain domination, distortion and unjustice. The purpose of critical school of thought concern on deliberative communication presenting rational discourse, hold on the principles of agree to disagree, respect to each other and giving an argument within the two-sided claims.

\section{RESULTS AND DISCUSSION}

First, there were many iMuslim websites belong to their Islamic school of thoughts. At least, there are 34 online media that affiliated to Wahabi-Salafi (Sunni). 22 of them had been bent due to their radical, extreme, and anti-Pancasila contents. The existing new media that belong to Wahabi-Salafi are: www.arrahmah.com, www nahimunkar.net, www.voa-islam, www.syiahindonesia.com. While some of the websites that belong to Shia groups are: http://www. almunawwarah.com, http://www.islamtimes.org/ms/; http://www.yapibangil, 
http://www. icc-jakarta, http://www. http://www. ahlulbaitindonesia.org, and http://www.lppimakassar.net, and http://www.majulah-ijabi.org,

The greatest number of websites belong to NU online. Approximately there are 100 websites circulated in new media. The objective of NU's online are defend from the combated of Wahabi-Salafi and sectarian websites that are propagate antiPancasila doctrines, Islamic radicalism, terrorism, and shia teaching.

Second, Islamic religious debates have been taking place not only between Sunni vs Shia, but also between NU vs Wahabi-Salafi. Religious practices such as maulid (commemoration of the Prophet birth), tabarruk (seeking blessing) and tawassul (intermediary) are viewed as "innovations" (bid'a). Meanwhile Wahabi-Salafi views Shia as kafir (apostacy), "komunis" (communist), and "danger" [11]. The other targets of Salafi-Wahabi movement is prohibition of Jemaat Ahmadiyya with reason is accused as non-believers. However, Wahabi-Salafi itself, by NU's online is accused as "takfiri" (doctrine to judge the others Muslim as apostasy), "pengikut palsu al-salaf al-salih" (the pseudo adherent of the righteous ancestors), intolerance, and claimed that his faith was the most truthful [12].

The confrontation between Sunni and Shia in Indonesia, is influenced by the propaganda warfare through new media in Middle East. Yamani [13] reported that: "The hundreds of Wahabi websites that call for the outright elimination of Shi'ites (killing a Shia Muslim merits more ajr, or reward in heaven). Shia describes as heretics and "enemies of God", and often conspired with Muslim enemies. Shia was accused helping Mongols destroy the Abbasid caliphate in 1258. While Siegel [14] has identified vocabulary of online sectarianism to depict a stereotype of both Shia and Sunni. Shia are labelled as Hizb al-Syaitan (party of devil), Rafidha (rejectionist), Nusyairi (followers of Nusayri as founder of Alawite), Safawi (Safavid), and Majus term that reference to Zoroastrianism).

While Sunni labelling in sectarian discourses are characterized by Wahhabi (a follower of Abd al-Wahhab), Takfiri (a Sunni Muslim who accuses another Muslim of apostacy), Nasibi (references to Umayyad Empire and those who hate the family of Muhammad), and Umawi (those who committed historical injustices against Shia).

Makdisi viewed sectarianism as discourse [15]. It contains emotional or aggressive communication. Hate speech is part of aggressive communication and it was growing when sectarianism underwent strengthening. Jarman [16], states "sectarianism refers to hatred against a group of persons...by reference to religious belief, colour, race, nationality (including citizenship) or ethic or national origin".

After Islamic revolution, Iran has been playing a significant role in Middle East. Conflicts in Syria, Yemen, Lebanon and Iraq, did not separate from Iran involvement. The terms, "Shia crescent", or "Shia threat" came into existence throughout the world, especially in the Middle East. Saudi was one of the monarchy states, that threatened by Iran. He used religious sentiment by using Wahabi sectarianism to block Iran penetration in regional area. By exploiting the oil power, Saudi spent a lot of budgets in supporting Wahabi influence through the world, including Indonesia.

Sunni-Shia sectarianism, according to Fuller [17], "are much exaggerated by the outside world", and "it also be thought of as a colonial strategy" [18]. Fuller adds, that: "The Bush administration and the neoconservatives have most recently latched on to the issue". Thus, America is one of main factor in strengthening sectarianism in Middle East. Another factors, some of regional states in Middle East, take reference to etno-nationalism ideologies or political instrument in order to maintain their power. While, according to critical communication theory, the growth of sectarianism was resulted of domination in political communication and "systematically distorted communication" [19].

\section{CONCLUSIONS}

To Nasr [20], "sect is a fundamental element of Muslim identity". Although there are Islamic diversities in theologies, practices, and cultures, they often lived with neighbors of the opposite sect, and intersectarian marriage was common" [21]. Only political elites who claims as if on behalf of Islam, make Muslim communities disunity and fragmented.

To those Muslim whose have been enlightened, their mission in the future are create Islamic deliberative democracy on the new media. Deliberative means discussion or dialogue. While dialogue is part of democracy. It means all Muslim should be discussed rationally, open mind, respect each other without living their own Islamic sectarian. Let's sects as a part of Muslim identity, live as it are because we cannot avoided it. There is no other way except to accept it with open heart.

\section{REFERENCES}

[1] Azzie, Abdurrahmane "Islam in Cyberpace: Muslim Presence on the Internet”, Islamic Studies 38:1. 1999.

[2] Dewdney, Andrew and Ride, Peter, "The New Media Handbook". London and New York. 2016.

[3] Bunt, Gary R. "iMuslim: Rewiring the House of Islam". Chapel Hill: The University of North Carolina Press. 2009.

[4] Hoffman, Thomas and Larson, Goran. "Muslim and the New Information and Communication Technologies". Springer. 2013.

[5] Campbell, Heidi A. "Digital Religion: Understanding Religious Practice in New media Worlds". London and New York: Routledge. 2013.

[6] Habermas, Jurgen, "Between Fact and Norms: Contribution to a Discourse Theory of Law and Democracy". Cambridge: MIT Press. 1996.

[7] El-Nawawy, Mohammed and Khamis, Sahar, "Islam Dot Com: Contemporary Islamic Discourse in Cyberspace". London: Palgrave Macmillan. 2009.

[8] Maghaireh, Alaeldin "Shariah Law and Cyber-Sectarian Conflict: How can Islamic Criminal Law Respond to Cyber-Crime". International Journal of Cyber Criminology, Vol. 2, Issue 2. 2008.

[9] Soreal, Sarah "Hate Speech and Distorted Communication: Rethinking the Limit of Incetement". Law and Philosophy. Springer. 2014.

[10] Kathrine, Gelber "Speaking Back: The Free Speech vs Hate Speech". Amsterdam: John Benjamin Publishing Company. 2002.

[11] Ida, Rachmah "Cyberculture and Sectarianism in Indonesia: The Rise of Shia Media and Anti-Shia Online Movement". Jurnal Komunikasi Islam. Vol. 6 No.2. 2016.

[12] Http://www.dutaislam (3/9/17) 
[13] Yamani, Mai "The Two Faces of Saudi Arabia". Survival, Volume 20. 2008

[14] Siegel, Alexandra "Sectarian Twitter Wars: Sunni-Shia Conflict and Cooperation in the Digital Age". Washington: Carnegie Endowment for International Peace. 2015.

[15] Makdisi, Ussama "The Culture of Sectarianism: Community, History, and Violence in Nineteenth-Century Ottoman Lebanon". Berkeley, Los Angeles and London: University of California Press. 2000.

[16] Jarman, "Neil Defining Sectarianism and Sectarian Hate Crime". Northern Ireland: The Special EU Programmes Body. 2012.
[17] Fuller, Graham "The Shia vs Sunni Split? Not on the Arab Street”. NPQ. 2006.

[18] Makdisi, "The Mythology of the Sectarian Middle East". Center for Middle East. Ussama 2017.

[19] Habermas, Jurgen "Systematically Distorted Communication”, Inquiry, Vol.13. 2013.

[20] Nasr, Vali The Shia Revival: How Conflicts within Islam Will Shape the Future. New York and London: W.W. Norton and Company. 2006.

[21] Thurber, Ches "From Coexistence to Cleancing: The Rise of Secatarian Violence in Baghdad, 2003-2007”, al-Nakhlah. USA: Tufts University. 2011 . 